\title{
When working is not enough: food insecurity in the Canadian labour force
}

\author{
Lynn Mclntyre ${ }^{1, *}$, Aaron C Bartoo ${ }^{1}$ and JC Herbert Emery ${ }^{2}$ \\ 'Department of Community Health Sciences, Faculty of Medicine, University of Calgary, Teaching Research \\ \& Wellness (TRW) Building, Room 3E14 (3rd Floor), 3280 Hospital Dr. NW, Calgary, Alberta, Canada, \\ T2N 4Z6: ${ }^{2}$ Department of Economics, Faculty of Arts, University of Calgary, Calgary, Alberta, Canada
}

Submitted 27 January 2012: Final revision received 23 July 2012: Accepted 1 August 2012: First published online 10 September 2012

\begin{abstract}
Objective: Food insecurity, lack of access to food due to financial constraints, is highly associated with poor health outcomes. Households dependent on social assistance are at increased risk of experiencing food insecurity, but food insecurity has also been reported in households reporting their main source of income from employment/wages (working households). The objective of the present study was to examine the correlates of food insecurity among households reliant on employment income.

Design: Working households reporting food insecurity were studied through analysis of the Canadian Community Health Survey, 2007-2008, employing descriptive statistics and logistic regression. Food insecurity was measured using the Household Food Security Survey Module; all provinces participated.

Setting: Canada.

Subjects: Canadian households where main income was derived through labour force participation. Social assistance recipients were excluded.

Results: For the period 2007-2008, 4\% of working households reported food insecurity. Canadian households reliant on primary earners with less education and lower incomes were significantly more likely to experience food insecurity; these differences were accentuated across some industry sectors. Residence in Quebec was protective. Working households experiencing food insecurity were more likely to include earners reporting multiples jobs and higher job stress. Visible minority workers with comparable education levels experienced higher rates of food insecurity than European-origin workers.

Conclusions: Reliance on employment income does not eliminate food insecurity for a significant proportion of households, and disproportionately so for households with racialized minority workers. Increases in work stress may increase the susceptibility to poor health outcomes of workers residing in households reporting food insecurity.
\end{abstract}

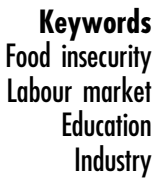

Food insecurity is defined as the inability to acquire or consume an adequate diet quality or sufficient quantity of food in socially acceptable ways, or the uncertainty that one will be able to do so,(1). Food-insecure households exhibit poor diet quality ${ }^{(2,3)}$ and are at risk for poor physical and mental health outcomes, likely associated with lack of healthy eating and overall stress ${ }^{(4)}$.

The strongest predictor of food insecurity is family poverty status, with households in the lowest income brackets found to be the most vulnerable ${ }^{(5,6)}$. In Canada, households that receive social assistance report the highest rates of food insecurity ${ }^{(7)}$. In 2004, for example, the Canadian Community Health Survey (CCHS) found that $59.7 \%$ of households whose main source of income was social assistance were food insecure ${ }^{(8)}$. Provincial and federal governments in Canada have sought to improve poverty outcomes such as food insecurity by reducing the number of households dependent on income transfers such as social assistance. Using approaches such as training opportunities and wage subsidies, members of lower-income households have been encouraged to rely much more on employment earnings than on social assistance ${ }^{(9,10)}$. However, for many households, the result has been that members shift their rank from the 'welfare poor' to the 'working poor $^{\text {(11) }}$. In $2007,31 \%$ of all families with a household income below the low income cut-off had worked over $910 \mathrm{~h}$ (i.e. a standard measure of annual labour force engagement) ${ }^{(12)}$, representing $5 \cdot 9 \%$ of all workers in Canada. Of these, $76 \%$ reported having full-time, full-year 
work, indicating a strong attachment to the labour market $^{(12)}$. In addition, $52 \%$ of individuals whose household income was below the low income cut-off earned wages higher than the minimum wage ${ }^{(11)}$, indicating that they were remunerated at a variety of pay scales beyond a legislated minimum.

The working poor, defined as those whose household incomes are below the low income cut-off, are also counted among the food insecure. Food banks report a substantial number of users from among the working poor; in 2011, $17.9 \%$ of clients reported current employment as their primary source of income ${ }^{(13)}$. In the 2004 CCHS survey, food insecurity was reported in $7 \cdot 3 \%$ of households whose main source of income was salary and wages ${ }^{(8)}$. Indeed, in terms of absolute numbers, food insecurity among the working poor exceeds that among social assistance and other income transfer recipients. Beyond this evidence of food insecurity among poor working households, to date there has been no thorough characterization of food insecurity within Canadian households dependent on working for their source of income. In addition to identifying characteristics of vulnerable workers in such households, an examination of food insecurity in food-insecure working households could suggest working conditions that predispose or protect against food insecurity and reveal coping strategies used by food-insecure workers. For example, if workers in some industries are associated with higher risk of household food insecurity, then we would have some understanding of how cyclical and trend changes in labour market conditions are impacting vulnerable households. In addition, by understanding which industries are associated with a higher risk of food insecurity, we can investigate labour market policies and regulations that might be suitable for improving employment conditions and earnings characteristics (levels and volatility). The objective of the present study, therefore, was to broadly examine the correlates of food insecurity among households reliant on employment income.

\section{Methods}

\section{Data}

Data were drawn from CCHS Cycle $4 \cdot 1$, spanning the calendar years of 2007 and 2008. Using a sampling strategy designed to achieve representativeness of the Canadian population, total respondent numbers for CCHS 4.1 were 132080 individuals. For the present analysis, individuals with missing responses to data for food insecurity questions were dropped, and data were further restricted to working ages (greater than 18 and less than 65 years of age). Furthermore, only respondents reporting wages/salary and/or self-employment as the main source of household income were included. Respondents were excluded if any household income was derived from social assistance or welfare. These exclusions ensured that the data represented households reliant upon participation in the labour force. Final respondent numbers appear in Table 1 . The study received ethical approval from the Conjoint Health Research Ethics Board at the University of Calgary.

Food insecurity was ascertained through administration of the US Department of Agriculture's Household Food Security Survey Module. The Household Food Security Survey Module contains eighteen questions about the food security situation in the household (related to lack of money or ability to afford food) over the previous 12 months: ten questions are specific to the experiences of adults in the household, and eight questions are specific to children. The US Department of Agriculture's scoring system was used in this analysis, i.e. households were considered food insecure if respondents answered two or more of both the adult and child (if applicable) questions in the affirmative ('yes'; 'often'; 'sometimes'; 'almost every month'; 'some months but not every month') ${ }^{(14)}$. Food insecurity was considered present or not and encompassed both compromises in diet quality as well as inadequate consumption.

\section{Covariates}

Covariates used in our analyses reflected households known to be vulnerable to food insecurity in Canada, such as those related to household composition, e.g. lone parent-led households, higher numbers of children and Aboriginal members ${ }^{(15,16)}$. Because food insecurity is measured as a household characteristic, where possible we used household measures such as home ownership, region of residence, marital status and household income. Given that personal information was not available for all household members, we used sex, age group, race and education of respondents as representative of household characteristics for general descriptive purposes.

For analyses aimed at characterizing the food-insecure worker rather than the household, we included only the primary earner in the household on the basis that their personal income exceeded $50 \%$ of household income. Note that we cannot know for certain if these individuals were personally food insecure, just that they lived in households reporting food insecurity. As primary earners, we considered their personal income, hours of work per week, whether or not they worked at multiple jobs and their reported job stress as measured by a five-point Likert scale, with ratings of $4=$ 'quite a bit stressful' and $5=$ 'extremely stressful' deemed high work stress. Hours per week was based on respondents' report of hours worked in a typical week.

Previous research has identified that working in the sales and service sector increases the probability of being poor ${ }^{(11)}$. The CCHS obtained information on respondents' industry of employment (North American classification), allowing for analysis of food insecurity in specific industrial 
sectors. We examined the primary earner's attachment to specific industry sectors of the labour market and its correlation with household food insecurity. To be certain that the industry sector was that of the primary earner in the household, again only respondents with a personal income greater than or equal to $50 \%$ of the household income were included in these analyses.

Finally, because skilled and unskilled workers are not interchangeable for employers ${ }^{(9,17-21)}$, it may be that labour market conditions and outcomes differ across skill groups, which in turn affects the risk of a household being food insecure ${ }^{(8)}$. Using education level as a proxy measure for skill level in the context of the workplace, for an examination of educational attainment and food insecurity by industrial sector, we stratified our sample according to the primary earner's educational attainment.

\section{Analyses}

Descriptive statistics were conducted using population weights provided by Statistics Canada. Cell sizes less than 15 are not disclosed according to Statistics Canada protocol. Statistical comparisons between the distribution of these sociodemographic factors among food-insecure and food-secure working households were performed using $t$ tests $(P<0.05$ considered significant). In addition, simple bivariate analysis was employed to investigate the odds of food insecurity in households where primary earners reported working multiple jobs as well as high work stress. We also examined if there were multiple earners in the household to consider the buffering capacity of other earners to withstand household food insecurity if the primary earner's work situation changes.

To determine if primary earners in specific industry sectors were at higher odds of living in food-insecure households, multivariate logistic regression with bootstrapping was used for the dichotomous outcome of food insecurity, adjusting for workforce and sociodemographic characteristics as a whole (including education as an effect modifier), and stratified by high school education or less $v$. greater. Education stratification in this case served to denote skill level (low for high school education or less $v$. higher for other educational attainment).

\section{Results}

\section{Sociodemographic characteristics of food- insecure working bouseholds}

Food insecurity among households reliant on employment earnings for income was $4 \%$ in 2007-2008. In comparison, food insecurity in the general population for that time period using the US Department of Agriculture scoring was $7 \cdot 1 \%{ }^{(22)}$. A majority of food-insecure working households were female-led, typically younger and with slightly more children under the age of 12 years than food-secure working households (Table 1). A larger percentage of food-insecure working households were lone parent-led and a significantly lower percentage owned their own home compared with food-secure working households. Although European-origin households represented the highest proportion of working households in our sample, they were under-represented in food-insecure working households, whereas African-origin and Aboriginal working households were significantly over-represented (Table 1).

Despite working an average of $40 \mathrm{~h} /$ week, both personal and household incomes were significantly lower for members of food-insecure working households compared with their working food-secure counterparts. Median annual household income in 2007-2008 for working food-secure households was \$CAN 70000 , while household income for food-insecure working households was \$CAN 34000 (Table 1).

\section{Work characteristics, industry and educational attainment of primary earners in food-insecure bousebolds}

Turning next to the examination of primary earners in working food-secure and food-insecure households, bivariate analysis demonstrated that primary earners in food-insecure households were significantly more likely to report working multiple jobs (OR $=1 \cdot 48 ; 95 \%$ CI $1 \cdot 20$, $1 \cdot 82)$ and to report higher job stress (OR $=1 \cdot 21 ; 95 \% \mathrm{CI}$ $1 \cdot 04,1.42)$ than workers in food-secure households.

The prevalence of food insecurity varied considerably across industrial sectors (Table 2). The highest percentage of food insecurity was observed among the accommodation/food service and administration sectors. Low percentages of food insecurity were observed for public administration and education.

Workers with education beyond high school typically demonstrated lower percentages of household food insecurity across industry sectors; the lowest rate was observed among workers who had obtained at least a bachelor's degree (Table 2). However, food insecurity percentages demonstrated some variation among education groups below the bachelor's level, indicating that the impact of education level may be sector-specific. Overall, industries with higher rates of food insecurity demonstrated greater percentages of workers with a high school diploma or less. In contrast, industries with lower percentages of food insecurity typically had a greater density of workers with a bachelor's education (Table 2).

Multivariate logistic regression revealed that increasing income independently decreased the odds of food insecurity in Canadian working households, as did having multiple earners in the household (Table 3). With the exception of wholesale trade, there was no association between industry sector and household food insecurity. However, when the sample was stratified by education (workers with and without attainment beyond high school), differences were observed, particularly among 
Table 1 Sociodemographic and workforce characteristics of food-secure and food-insecure working households ( $n$ 41802), Canadian Community Health Survey (CCHS) Cycle $4 \cdot 1$ (2007-2008)

\begin{tabular}{|c|c|c|}
\hline & Food secure ( $n$ 40205) & Food insecure ( $n$ 1597) \\
\hline Total workforce ( $n$ 41 802; \%) & $96 \cdot 1$ & $3 \cdot 9$ \\
\hline Female (\%) & $44 \cdot 4$ & $57 \cdot 0^{*}$ \\
\hline \multicolumn{3}{|l|}{ Age (years) } \\
\hline Mean & $40 \cdot 4$ & $37 \cdot 0^{*}$ \\
\hline SE & 0.09 & 0.38 \\
\hline No. of children aged $<12$ years & 0.43 & $0 \cdot 60^{*}$ \\
\hline Lone parent (\%) & $1 \cdot 3$ & $4 \cdot 6^{\star}$ \\
\hline Home ownership (\%) & $75 \cdot 8$ & $37 \cdot 8^{*}$ \\
\hline \multicolumn{3}{|l|}{ Workforce $(n 41802)$} \\
\hline Median annual personal income (\$CAN) & 43000 & $25000^{*}$ \\
\hline Median annual household income (\$CAN) & 70000 & $34000^{*}$ \\
\hline Multiple jobs (\%) & $9 \cdot 1$ & $12 \cdot 9^{*}$ \\
\hline High work stress (\%) & $31 \cdot 7$ & $36 \cdot 0^{*}$ \\
\hline \multicolumn{3}{|l|}{ Hours worked/week } \\
\hline Mean & $41 \cdot 8$ & $39 \cdot 6^{*}$ \\
\hline SE & 0.09 & 0.39 \\
\hline \multicolumn{3}{|l|}{ Education (\%) n 40863} \\
\hline$<$ High school diploma & $2 \cdot 8$ & $6 \cdot 9^{*}$ \\
\hline High school diploma & 8.6 & $15 \cdot 2^{*}$ \\
\hline Some post-secondary & $5 \cdot 0$ & $11 \cdot 0^{*}$ \\
\hline Trade school & $11 \cdot 7$ & $14 \cdot 0$ \\
\hline Other certificate/diploma & $32 \cdot 4$ & $33 \cdot 6$ \\
\hline Bachelor's or more & $39 \cdot 5$ & $19 \cdot 3^{*}$ \\
\hline \multicolumn{3}{|l|}{ Ethnicity ( $(n 1677 ; \%)$} \\
\hline European-origin & $82 \cdot 6$ & $67 \cdot 8^{*}$ \\
\hline African-origin & $2 \cdot 0$ & $10 \cdot 3^{*}$ \\
\hline Asian-origin & $9 \cdot 8$ & $11 \cdot 7$ \\
\hline Aboriginal & $2 \cdot 6$ & $6 \cdot 1^{*}$ \\
\hline Other & 3.0 & $4 \cdot 1$ \\
\hline \multicolumn{3}{|l|}{ Marital status ( $n$ 41765; \%) } \\
\hline Married/common law & $68 \cdot 3$ & $47 \cdot 5^{\star}$ \\
\hline Separated/widowed & $8 \cdot 7$ & $19 \cdot 6^{*}$ \\
\hline Single & $23 \cdot 0$ & $32 \cdot 9^{*}$ \\
\hline \multicolumn{3}{|l|}{ Region ( $n 41802 ; \%$ ) } \\
\hline Atlantic Canada & $6 \cdot 5$ & $6 \cdot 7$ \\
\hline Quebec & $23 \cdot 5$ & $17 \cdot 2^{*}$ \\
\hline Ontario & 39.5 & $42 \cdot \overline{8}$ \\
\hline Western Canada & $30 \cdot 3$ & $32 \cdot 9$ \\
\hline Territories & 0.3 & $0 \cdot 4^{*}$ \\
\hline
\end{tabular}

NB: Not all rows and columns total $100 \%$ due to rounding. ${ }^{*}$ Significantly different from food secure, $P<0.05$.

industry sectors. In the mining/oil/gas industry, wholesale and retail trade, administration and accommodation/ food service sectors, workers with only a high school diploma or less were significantly more likely to live in food-insecure households compared with workers with this level of education in the health-care industry. In contrast, industry variables were not significant for workers with education beyond high school, except for the accommodation/food service industry which demonstrated lower odds of food insecurity compared with health-care workers with this higher level of education. Therefore, the likelihood of living in a foodinsecure household for workers with only a high school education or less was associated not only with household and income variables but also with the industry sector in which they worked.

Of note, workers residing in Quebec had significantly reduced odds of being food insecure by almost $60 \%$ compared with workers in Ontario. This decreased likelihood was observed regardless of educational attainment and was more pronounced for workers with only high school education (Table 3 ).

\section{Discussion}

The present study describes household food insecurity among Canadian working households, i.e. those reliant on employment income. We found that income is a significant factor affecting the odds of being food insecure, as incomes in food-insecure households were considerably lower than those in food-secure households. By implication, policies that encourage full employment may not mitigate poverty if the wages earned by the most vulnerable workers are insufficient to eliminate their susceptibility to food insecurity.

The lower earnings of workers in food-insecure households despite full-time hours of work in a typical week, 
Table 2 Household food insecurity by primary earner's industry sector and educational attainment ( $n 31619$ ), Canadian Community Health Survey (CCHS) Cycle 4.1 (2007-2008)

\begin{tabular}{|c|c|c|c|c|c|c|c|}
\hline \multirow[b]{2}{*}{ Industry } & \multicolumn{7}{|c|}{ Food insecurity (\%) } \\
\hline & Total & $\begin{array}{l}<\text { High } \\
\text { school }\end{array}$ & $\begin{array}{l}\text { High school } \\
\text { diploma }\end{array}$ & $\begin{array}{l}\text { Trade } \\
\text { school }\end{array}$ & $\begin{array}{c}\text { Other } \\
\text { certificate }\end{array}$ & $\begin{array}{l}\text { Some post- } \\
\text { secondary }\end{array}$ & $\geq$ Bachelor's \\
\hline Accommodation/food service & $10 \cdot 2$ & $19 \cdot 2$ & $24 \cdot 6$ & $7 \cdot 2$ & $3 \cdot 3$ & $3 \cdot 3$ & ND \\
\hline Administration & $10 \cdot 1$ & $6 \cdot 2$ & $13 \cdot 5$ & $8 \cdot 1$ & $13 \cdot 9$ & $8 \cdot 8$ & $2 \cdot 5$ \\
\hline Retail trade & $6 \cdot 6$ & $9 \cdot 1$ & $8 \cdot 1$ & $6 \cdot 9$ & $3 \cdot 6$ & $11 \cdot 7$ & $3 \cdot 9$ \\
\hline Other service & $6 \cdot 2$ & $3 \cdot 3$ & $10 \cdot 5$ & $3 \cdot 7$ & $6 \cdot 0$ & $14 \cdot 2$ & $5 \cdot 6$ \\
\hline Wholesale trade & $5 \cdot 8$ & $6 \cdot 1$ & $5 \cdot 4$ & $4 \cdot 8$ & $3 \cdot 3$ & $10 \cdot 7$ & $7 \cdot 2$ \\
\hline Arts and entertainment & $5 \cdot 8$ & $4 \cdot 8$ & ND & $12 \cdot 9$ & $8 \cdot 2$ & $7 \cdot 0$ & ND \\
\hline Real estate & $5 \cdot 6$ & ND & ND & ND & $4 \cdot 5$ & ND & ND \\
\hline Construction & $5 \cdot 2$ & $8 \cdot 8$ & $3 \cdot 9$ & $3 \cdot 8$ & $4 \cdot 4$ & $11 \cdot 1$ & $2 \cdot 6$ \\
\hline Health care & $4 \cdot 7$ & $5 \cdot 0$ & $4 \cdot 7$ & $3 \cdot 1$ & $6 \cdot 6$ & $9 \cdot 7$ & $2 \cdot 3$ \\
\hline Transport/warehousing & $4 \cdot 2$ & $4 \cdot 2$ & $2 \cdot 5$ & $5 \cdot 4$ & $6 \cdot 5$ & $1 \cdot 5$ & ND \\
\hline Manufacturing & $4 \cdot 0$ & $6 \cdot 8$ & $4 \cdot 2$ & $3 \cdot 0$ & $3 \cdot 1$ & $9 \cdot 8$ & $1 \cdot 8$ \\
\hline Professional/science/management & $2 \cdot 8$ & ND & $1 \cdot 9$ & $4 \cdot 4$ & $5 \cdot 7$ & $5 \cdot 4$ & $1 \cdot 1$ \\
\hline Agriculture/forestry/fishing & $2 \cdot 7$ & $2 \cdot 3$ & ND & ND & ND & $11 \cdot 4$ & ND \\
\hline Finance/insurance & $2 \cdot 3$ & ND & ND & ND & $2 \cdot 7$ & ND & $1 \cdot 4$ \\
\hline Information/culture & $2 \cdot 1$ & ND & ND & ND & $2 \cdot 2$ & $3 \cdot 2$ & $2 \cdot 0$ \\
\hline Public administration & $2 \cdot 0$ & $6 \cdot 5$ & $1 \cdot 7$ & $5 \cdot 5$ & $1 \cdot 7$ & $3 \cdot 5$ & $1 \cdot 2$ \\
\hline Education & $1 \cdot 9$ & ND & $1 \cdot 6$ & ND & $3 \cdot 4$ & ND & $1 \cdot 6$ \\
\hline Mining/oil/gas & $1 \cdot 4$ & $7 \cdot 3$ & ND & ND & ND & ND & ND \\
\hline
\end{tabular}

ND, not disclosed.

combined with a higher report of multiple jobs, suggests that food-insecure workers are attempting to make ends meet through work but have inadequate income to meet their budgetary needs. From our multivariate regression analysis we found that less educated workers demonstrated greater odds of reporting food insecurity in certain industry sectors such as accommodation and food services, independent of income. While we cannot exclude the possibility that the inherent characteristics of workers may vary between industry sectors, other explanations for differing food insecurity rates in various industry sections, despite similar annual incomes, merit consideration. It is possible that employment dimensions other than lower hourly wages contribute to food insecurity risk for workers. Possible employment characteristics that could increase food insecurity risk among workers include seasonal work, shift work, irregular hours, lack of union protection from lay-offs during cyclical slowdowns and lack of job mobility. These work characteristics could lead to fewer weeks worked and overall lower earnings, and/or income volatility. Volatile earnings can result in negative household income shocks that have been observed to be just as harmful to household material well-being as living in persistent low income ${ }^{(23)}$.

Seasonal employment represented $12 \cdot 9 \%$ of the Canadian workforce in $2007^{(24)}$, while $30 \%$ of employed Canadians worked non-standard hours ${ }^{(25)}$. From our regression, industry sectors with the highest percentage of seasonal employment (construction, forestry/fishing, public administration) ${ }^{(26)}$ did not show increased odds of food insecurity among workers with only a high school education. In contrast, industry sectors with significantly higher odds of food insecurity for this category of worker (accommodation/food service, administration, trade, mining/oil/gas) were among those with the highest number and percentage of shift workers in Canada ${ }^{(27)}$. The accommodation/food service sector, for example, includes the largest percentage of shift workers $(40 \%)^{(27)}$. Workers with low education in this industry may be particularly vulnerable to food insecurity due to income variation associated with shift work.

Jobs in different industries can also differ in terms of the variability of income due to sensitivity to the business cycle and due to differing rates of unionization, which provides more stable jobs and wages to unionized workers. Administration - a high food insecurity sector, for example, has one of the lowest rates of unionization in Canada $(6 \cdot 3 \%)^{(28)}$. In contrast, public administration and education, two sectors with very high rates of unionization $(67 \cdot 3 \%$ and $68 \cdot 3 \%$, respectively), had low rates of food insecurity.

Where skills are transferable and hence workers are mobile across industries, we would not expect to see industry as an important determinant of food insecurity, because workers would migrate from 'bad jobs' to 'good jobs $^{,(19,20)}$. We should see in this case that food insecurity prevalence is determined by a worker's skill level but not industry of employment. To find that industry of employment determines food insecurity risk after accounting for skill level suggests that workers are not mobile across industries. This lack of inter-industry mobility has been identified in studies examining the impact of Canada-USA free trade on Canadian workers ${ }^{(19,20)}$.

We also found an over-representation of Aboriginal and visible minority groups among the working food insecure, consistent with their over-representation in the food-insecure population as a whole ${ }^{(8)}$. Still, the finding 
Table 3 Multivariate regression analysis of odds for household food insecurity of primary earners as a whole and stratified by high school education, Canadian Community Health Survey (CCHS) Cycle 4.1 (2007-2008)

\begin{tabular}{|c|c|c|c|c|c|c|}
\hline & \multicolumn{6}{|c|}{ Food insecurity } \\
\hline & \multicolumn{2}{|c|}{$\begin{array}{l}\text { Total sample } \\
\text { (n 29 407) }\end{array}$} & \multicolumn{2}{|c|}{$\begin{array}{l}\leq \text { High school diploma } \\
(n 7174)\end{array}$} & \multicolumn{2}{|c|}{$\begin{array}{l}>\text { High school diploma } \\
\text { (n 22201) }\end{array}$} \\
\hline & OR & $95 \% \mathrm{Cl}$ & OR & $95 \% \mathrm{Cl}$ & OR & $95 \% \mathrm{Cl}$ \\
\hline \multicolumn{7}{|l|}{ Workforce variables } \\
\hline Respondent income per \$CAN 10000 increment & $0 \cdot 63^{*}$ & $0.58,0.68$ & $0 \cdot 74^{\star}$ & $0 \cdot 66,0.83$ & $0 \cdot 59^{*}$ & $0.54,0.65$ \\
\hline Mean hours worked/week per extra hour worked & 0.99 & $0 \cdot 99,1 \cdot 01$ & 0.99 & $0 \cdot 98,1 \cdot 01$ & $1 \cdot 00$ & $0.99,1.01$ \\
\hline Household earners $>1$ & $0 \cdot 56^{*}$ & $0.43,0.74$ & 0.69 & $0.45,1.06$ & $0.55^{*}$ & $0.40,0 \cdot 76$ \\
\hline \multicolumn{7}{|l|}{ Industry (ref. Health care) } \\
\hline Accommodation/food service & $1 \cdot 12$ & $0.65,1.92$ & $3 \cdot 93^{*}$ & $1 \cdot 69,9 \cdot 12$ & $0 \cdot 40^{*}$ & $0 \cdot 23,0 \cdot 71$ \\
\hline Administration & $1 \cdot 47$ & $0 \cdot 84,2 \cdot 56$ & $3 \cdot 16^{\star}$ & $1 \cdot 33,7 \cdot 53$ & $1 \cdot 35$ & $0 \cdot 68,2 \cdot 68$ \\
\hline Retail trade & $1 \cdot 11$ & $0 \cdot 76,1 \cdot 63$ & $2 \cdot 21^{*}$ & $1 \cdot 02,4 \cdot 79$ & $0 \cdot 89$ & $0.58,1.37$ \\
\hline Other service & $1 \cdot 24$ & $0 \cdot 71,2 \cdot 14$ & 1.55 & $0 \cdot 57,4 \cdot 23$ & $1 \cdot 19$ & $0 \cdot 65,2 \cdot 16$ \\
\hline Wholesale trade & $2 \cdot 15^{\star}$ & $1 \cdot 11,4 \cdot 18$ & $3 \cdot 37^{\star}$ & $1 \cdot 30,8 \cdot 73$ & $2 \cdot 18$ & $0 \cdot 92,5 \cdot 18$ \\
\hline Arts and entertainment & 1.03 & $0.59,1 \cdot 83$ & 0.97 & $0 \cdot 32,2 \cdot 89$ & $1 \cdot 12$ & $0 \cdot 59,2 \cdot 12$ \\
\hline Real estate & $1 \cdot 67$ & $0 \cdot 59,4 \cdot 71$ & $6 \cdot 50^{*}$ & $1 \cdot 35,31 \cdot 17$ & 0.90 & $0 \cdot 37,2 \cdot 18$ \\
\hline Construction & $1 \cdot 47$ & $0 \cdot 90,2 \cdot 40$ & $2 \cdot 46$ & $0.91,6.66$ & $1 \cdot 41$ & $0 \cdot 82,2 \cdot 45$ \\
\hline Transport/warehousing & $1 \cdot 12$ & $0 \cdot 65,1.94$ & $1 \cdot 15$ & $0 \cdot 42,3 \cdot 14$ & $1 \cdot 42$ & $0 \cdot 79,2 \cdot 55$ \\
\hline Manufacturing & $1 \cdot 25$ & $0 \cdot 85,1 \cdot 83$ & $1 \cdot 83$ & $0 \cdot 82,4 \cdot 07$ & $1 \cdot 21$ & $0.77,1.90$ \\
\hline Professional/science/management & $1 \cdot 14$ & $0 \cdot 70,1 \cdot 86$ & 0.62 & $0 \cdot 17,2 \cdot 34$ & $1 \cdot 15$ & $0.69,1.92$ \\
\hline Agriculture/forestry/fishing & 0.63 & $0 \cdot 30,1 \cdot 31$ & $0 \cdot 72$ & $0 \cdot 24,2 \cdot 14$ & $0 \cdot 86$ & $0 \cdot 35,2 \cdot 13$ \\
\hline Finance/insurance & 0.68 & $0 \cdot 36,1 \cdot 26$ & ND & & $0 \cdot 81$ & $0.43,1.53$ \\
\hline Information/culture & $0 \cdot 82$ & $0 \cdot 40,1 \cdot 65$ & 0.68 & $0 \cdot 15,3 \cdot 20$ & $0 \cdot 87$ & $0 \cdot 40,1 \cdot 88$ \\
\hline Public administration & 1.03 & $0 \cdot 64,1 \cdot 68$ & $1 \cdot 24$ & $0 \cdot 44,3 \cdot 50$ & $1 \cdot 06$ & $0 \cdot 61,1 \cdot 83$ \\
\hline Education & 0.62 & $0 \cdot 32,1 \cdot 20$ & 0.60 & $0 \cdot 18,2 \cdot 01$ & 0.62 & $0 \cdot 31,1 \cdot 27$ \\
\hline Mining/oil/gas & $1 \cdot 04$ & $0 \cdot 47,2 \cdot 28$ & $3 \cdot 58^{*}$ & $1 \cdot 08,11 \cdot 88$ & $0 \cdot 48$ & $0 \cdot 16,1 \cdot 39$ \\
\hline \multicolumn{7}{|l|}{ Sociodemographic variables } \\
\hline Female & $1 \cdot 17$ & $0 \cdot 95,1 \cdot 44$ & $1 \cdot 23$ & $0 \cdot 85,1 \cdot 78$ & $1 \cdot 13$ & $0.88,1.44$ \\
\hline No. of children aged $<12$ years & $1 \cdot 04$ & $0 \cdot 86,1 \cdot 25$ & $0 \cdot 86$ & $0 \cdot 63,1 \cdot 18$ & $1 \cdot 14$ & $0.91,1.43$ \\
\hline Mean household size & $1 \cdot 28^{*}$ & $1 \cdot 10,1 \cdot 50$ & $1 \cdot 19$ & $0.94,1.52$ & $1 \cdot 30^{*}$ & $1 \cdot 09,1 \cdot 55$ \\
\hline Home-owner & $0.43^{*}$ & $0.33,0.55$ & $0 \cdot 37^{\star}$ & $0.25,0.54$ & $0 \cdot 41^{*}$ & $0.31,0.55$ \\
\hline Lone parent & $1 \cdot 91^{*}$ & $1 \cdot 40,2 \cdot 62$ & $1 \cdot 92^{*}$ & $1 \cdot 16,3 \cdot 19$ & $1 \cdot 80^{*}$ & $1 \cdot 27,2 \cdot 56$ \\
\hline \multicolumn{3}{|l|}{ Respondent education (ref. High school diploma) } & \multicolumn{2}{|c|}{$\begin{array}{l}\text { Respondent education } \\
\text { (ref. High school diploma) }\end{array}$} & \multicolumn{2}{|c|}{$\begin{array}{l}\text { Respondent education } \\
\text { (ref. } \geq \text { Bachelor's) }\end{array}$} \\
\hline$<$ High school diploma & $1 \cdot 26$ & $0 \cdot 83,1 \cdot 90$ & $1 \cdot 37$ & $0.94,1.92$ & - & - \\
\hline Some post-secondary & $1 \cdot 42$ & $0.98,2.07$ & - & - & $1 \cdot 57^{\star}$ & $1 \cdot 03,2 \cdot 38$ \\
\hline Trade school & $1 \cdot 02$ & $0 \cdot 71,1 \cdot 49$ & - & - & $1 \cdot 11$ & $0 \cdot 72,1 \cdot 71$ \\
\hline Other certificate & 0.97 & $0 \cdot 70,1 \cdot 34$ & - & - & 1.09 & $0.75,1.57$ \\
\hline$\geq$ Bachelor's & $0 \cdot 85$ & $0.55,1.33$ & - & - & - & - \\
\hline \multicolumn{7}{|l|}{ Respondent age (ref. 35-44 years) } \\
\hline 18-24 years & 0.84 & $0.58,1 \cdot 20$ & 0.78 & $0 \cdot 47,1 \cdot 32$ & $0 \cdot 87$ & $0.55,1.40$ \\
\hline $25-34$ years & $0 \cdot 88$ & $0 \cdot 68,1 \cdot 15$ & $0 \cdot 89$ & $0 \cdot 57,1 \cdot 41$ & 0.92 & $0 \cdot 68,1 \cdot 25$ \\
\hline $45-54$ years & $1 \cdot 28$ & $0.90,1 \cdot 83$ & $0 \cdot 76$ & $0 \cdot 42,1 \cdot 34$ & $1 \cdot 64^{*}$ & $1 \cdot 09,2 \cdot 45$ \\
\hline $55-65$ years & $0.51^{*}$ & $0 \cdot 35,0.74$ & $0 \cdot 37^{\star}$ & $0 \cdot 22,0.61$ & $0.57^{\star}$ & $0.36,0.91$ \\
\hline \multicolumn{7}{|l|}{ Ethnicity (ref. European-origin) } \\
\hline African-origin & $2 \cdot 60^{*}$ & $1 \cdot 46,4 \cdot 62$ & $4 \cdot 28^{*}$ & $1 \cdot 81,10 \cdot 15$ & $2 \cdot 15^{\star}$ & $1 \cdot 17,3 \cdot 94$ \\
\hline Asian-origin & $0 \cdot 77$ & $0 \cdot 48,1 \cdot 24$ & $1 \cdot 87$ & $0 \cdot 87,4 \cdot 01$ & $0 \cdot 46^{\star}$ & $0.25,0.85$ \\
\hline Aboriginal & $1 \cdot 22$ & $0 \cdot 84,1 \cdot 77$ & $1 \cdot 17$ & $0.68,1.54$ & $1 \cdot 20$ & $0.73,1.97$ \\
\hline Other & 1.06 & $0.59,1.92$ & 0.53 & $0 \cdot 18,1 \cdot 54$ & $1 \cdot 10$ & $0 \cdot 57,2 \cdot 13$ \\
\hline \multicolumn{7}{|l|}{ Region (ref. Ontario) } \\
\hline Atlantic Canada & $0 \cdot 80$ & $0.59,1.09$ & $0 \cdot 58^{*}$ & $0.35,0.97$ & 0.96 & $0.66,1.39$ \\
\hline Quebec & $0.44^{*}$ & $0 \cdot 32,0 \cdot 60$ & $0 \cdot 34^{*}$ & $0 \cdot 19,0.60$ & $0 \cdot 48^{*}$ & $0.33,0.69$ \\
\hline Western Canada & $1 \cdot 05$ & $0 \cdot 81,1 \cdot 35$ & $0 \cdot 74$ & $0 \cdot 50,1 \cdot 10$ & $1 \cdot 25$ & $0.92,1.71$ \\
\hline Territories & $1 \cdot 30$ & $0 \cdot 82,2 \cdot 05$ & $1 \cdot 69$ & $0 \cdot 78,3 \cdot 63$ & $1 \cdot 07$ & $0.59,1.94$ \\
\hline
\end{tabular}

ref., reference category; ND, not disclosed.

*Significant, $P<0.05$.

that ethnicity, independent of education, was predictive of food insecurity raises concern about racialization within the labour force. Food insecurity among racialized groups is especially concerning as the proportion of visible minority groups in the Canadian labour force is expected to increase substantially in the future ${ }^{(29,30)}$.
As previously mentioned, food insecurity is linked to poor health outcomes, the association of which is complex as poor health may limit employment opportunities and contribute to low income and food insecurity which in turn exacerbates poor health. Besides the risk for nutrition-related diseases such as allergies, diabetes mellitus, 
hypertension and cardiac disease $\mathrm{e}^{(31,32)}$, individuals experiencing food insecurity have poorer self-rated health ${ }^{(31)}$ as well as poorer oral health ${ }^{(33)}$; food insecurity has also been linked to mental health disorders ${ }^{(31,34)}$. Physical and mental health have important impacts on the labour market, affecting the capacity to work, labour force participation, wages and job security, and job choice ${ }^{(35)}$. Furthermore, poor health may deepen disparities in labour force participation among disadvantaged groups, such as members of visible minorities, lone parent-led households and workers of lower socio-economic status ${ }^{(36,37)}$. Therefore, the disadvantages associated with food insecurity may affect worker health and productivity due to increases in worker absenteeism, stress and social exclusion ${ }^{(38)}$.

From our current analysis, workers in food-insecure households are more likely to work multiple jobs, likely contributing to extended or irregular hours, and to report higher job stress compared with workers in food-secure households. Non-standard work hours (i.e. shift work) are thought to lead to poor health due to disruption in circadian rhythms and changes in lifestyles ${ }^{(39,40)}$, and have been associated with $\mathrm{CVD}^{(41,42)}$, hypertension ${ }^{(43)}$, gastrointestinal disorders ${ }^{(44)}$ and cancer ${ }^{(45)}$. Work-related stress is also a significant concern in the labour force, and considerable research has focused on the link between work stress and poor health/well-being. It has also been associated with $\mathrm{CVD}^{(46)}$, migraines and mental disorders $^{(47)}$, as well as poor health behaviors such as smoking and sleep disruption ${ }^{(48)}$. Work stress can be defined as a combination of different elements such as job strain, physical demands, job security, co-worker and supervisor support $^{(49)}$. Our measure of work stress is self-reported; therefore, we cannot attribute our results to any or all of these individual elements. However, because stress itself can lead to poor health, the increased work stress reported by workers experiencing food insecurity is concerning. Given the association with work stress and multiple jobs, workers living in food-insecure households may be a group particularly vulnerable to poor health outcomes.

In the current study, workers residing in Quebec were less likely to report food insecurity relative to other provinces, a result observed independent of education level. Quebec is considered to be a more socially progressive province than the rest of the country with policies that buttress a social economy ${ }^{(50,51)}$; this is likely reflected in Quebec having one of the lowest provincial rates of food insecurity in Canada ${ }^{(8)}$. In addition, Quebec has the lowest percentage of food insecurity among many of the vulnerable groups highlighted in the present study ${ }^{(52)}$. In 2004, the province of Quebec enacted its Government Action Plan to Combat Poverty and Social Exclusion ${ }^{(53)}$. Under this Action Plan, wage subsidization for low-waged workers was substantial. For example, from 2004 to 2007, a lone parent with a child under the age of 3 years working full time at minimum wage would have had a $23.3 \%$ increase in disposable income ${ }^{(53)}$. Because low-income families are constrained by a limited budget and devote a substantial portion of their monthly budget to food ${ }^{(54)}$, changes in disposable income such as those realized by lone mothers in Quebec likely impacted food expenditures and reduced food insecurity ${ }^{(55,56)}$.

To our knowledge, the present study is the first in-depth one to describe food insecurity within Canadian working households. The CCHS questionnaire has a limited set of labour force questions. It would have been helpful to have more information about work conditions, regularity of hours and income volatility. Despite these limitations, our results do show that the sociodemographic characteristics of working households experiencing food insecurity are similar to those of the general population, indicating that food insecurity is a systemic problem within Canada that is not fully resolved by encouraging persons to leave social assistance for paid employment. Less educated workers are particularly vulnerable, likely due to both low income and earnings volatility. Consequently, if the federal and provincial governments continue their agenda of addressing poverty through labour market initiatives, governments need to also address the employment conditions, earnings levels and variability, particularly for workers with lower education levels. Given the lower risk of food insecurity for households reliant on employment earnings in Quebec, the social, labour and economic policies of this province may provide a guide for other governments.

\section{Acknowledgements}

Source of funding: The study was supported by the Canadian Institutes of Health Research (operating grant number: MOP-89731). Conflicts of interest: No conflicts of interest declared. Authors' contributions: L.M. was responsible for overall design and execution of the study. A.C.B. led manuscript drafting and provided advice on analyses. J.C.H.E. suggested the analytic direction, interpretation of results and provided substantive contributions to the manuscript. Acknowledgements: The authors thank Olayemi Olabiyi, Jesse Matheson and Chantal Hansen for their technical assistance.

\section{References}

1. Davis B \& Tarasuk V (1994) Hunger in Canada. Agric Hum Values 11, 50-57.

2. Ricciuto L, Tarasuk V \& Yatchew A (2006) Socio-demographic influences on food purchasing among Canadian households. Eur J Clin Nutr 13, 1-13.

3. Ricciuto L \& Tarasuk V (2007) An examination of incomerelated disparities in the nutritional quality of food selections among Canadian households from 1986-2001. J Nutr 64, 186-198.

4. Tarasuk V (2008) Health implications of food insecurity. In Social Determinants of Health: Canadian Perspective, 2nd ed., pp. 205-220 [D Raphael, editor]. Toronto, ON: Canadian Scholars' Press Inc. 
5. Che J \& Chen J (2001) Food insecurity in Canadian households. Health Rep 12, 11-22.

6. McIntyre L, Walsh G \& Walsh G (2001) A Follow-Up Study of Child Hunger in Canada. Working Paper no. W-01-1-2E. Ottawa, ON: Applied Research Branch, Strategic Policy, Human Resources Development Canada; available at http://publications.gc.ca/collections/Collection/MP32-28-011-2E.pdf

7. McIntyre L, Connor SK \& Warren J (2000) Child hunger in Canada: results of the 1994 National Longitudinal Survey of Children and Youth. CMAJ 163, 961-965.

8. Health Canada (2007) Canadian Community Health Survey Cycle 2.2, Nutrition (2004): Income-Related Household Food Security in Canada. Ottawa, ON: Health Canada, Office of Nutrition Policy and Promotion, Health Products and Food Branch; available at http://www.hcsc.gc.ca/fn-an/surveill/nutrition/commun/income_food_secsec_alim-eng.php

9. Coe PJ \& Emery H (2004) The disintegrating Canadian labour market? The extent of the market then and now. Can J Econ 37, 879-897.

10. Milligan K \& Stabile M (2007) The integration of child tax credits and welfare: evidence from the Canadian National Child Benefit program. J Public Econ 91, 305-326.

11. Fleury D \& Fortin M (2006) When Working is not enough to Escape Poverty: An Analysis of Canada's Working Poor. Working Paper. Gatineau, QC: Policy Research Group, Human Resources and Social Development Canada; available at http://tamarackcommunity.ca/downloads/vc/When_ Work_Not_Enough.pdf

12. Human Resources and Skills Development Canada (2009) Low Income in Canada: 2000-2007. Using the Market Basket Measure. Final Report. Gatineau, QC: Human Resources Skills Development Canada; available at http:// www.rhdcc-hrsdc.gc.ca/eng/publications_resources/research/ categories/inclusion/2009/sp-909-07-09/sp_909_07_09e.pdf

13. Food Banks Canada (2011) HungerCount 2011. Toronto, ON: Food Banks Canada; available at http://foodbankscanada. ca/getmedia/dc2aa860-4c33-4929-ac36-fb5d40f0b7e7/HungerCount-2011.pdf.aspx

14. Bickel G, Nord M, Price C et al. (2000) Guide to Measuring Household Food Security, Revised 2000. Alexandria, VA: US Department of Agriculture, Food and Nutrition Service; available at http://www.fns.usda.gov/fsec/files/fsguide.pdf

15. Ledrou I \& Gervais J (2005) Food insecurity. Health Rep 16, $47-50$.

16. McIntyre L \& Rondeau K (2008) Food insecurity. In Social Determinants of Health: Canadian Perspectives, 2nd ed., pp. 188-204 [D Raphael, editor]. Toronto, ON: Canadian Scholars' Press Inc.

17. Coe PJ \& Emery H (2012) Accreditation requirements and the speed of labour market adjustment in Canadian building trades. Can Public Policy 38, 91-111.

18. Beaudry P \& Green DA (2000) Cohort patterns in Canadian earnings: assessing the role of skill premia in inequality trends. Can J Econ 33, 907-936.

19. Beaulieu E (2000) The Canada-US Free Trade Agreement and labour market adjustment in Canada. Can J Econ 33, 540-563.

20. Beaulieu E (2002) Factor or industry cleavages in trade policy? An empirical analysis of the Stolper-Samuelson Theorem. Econ Polit 14, 99-131.

21. Sattinger M (2006) Overlapping labour markets. Labour Econ 13, 237-257.

22. McKee B, Foster, LT, Keller PC et al. (2009) Nutrition, food security, and alcohol consumption. In: The Geography of Wellness and Well-being across Canada, pp. 53-71. Victoria, BC: Department of Geography, University of Victoria; available at http://www.geog.uvic.ca/wellness/ bccomparisons/4Nutrition.pdf
23. Leete L \& Bania N (2010) The effect of income shocks on food insufficiency. Rev Econ Household 8, 505-526.

24. Statistics Canada (2009) The Canadian Labour Market At A Glance 2007. Catalogue no. 71-222-X. Ottawa, ON: Statistics Canada, Labour Statistics Division; available at http://www. statcan.gc.ca/pub/71-222-x/71-222-x2008001-eng.pdf

25. Shields M (2002) Shift work and health. Health Rep 13, 11-33.

26. Guillemette R, L'Italien F \& Grey A (2000) Seasonality of Labour Markets. Comparison of Canada, the US and the Provinces. Hull, QC: Applied Research Branch, Strategic Policy, Human Resources Development Canada; available at http://publications.gc.ca/collections/Collection/MP3229-00-8E.pdf

27. Demers PA, Wong I \& McLeod C (2010) The prevalence of shift work in Canada. Presented at Scientific Symposium on the Health Effects of Shift Work, Toronto, 12 April 2010; available at http://www.iwh.on.ca/shift-work-symposium/ demers

28. Business Council of British Columbia (2006) Trends in union density across Canada. Ind Rel Bull 38, 1-2.

29. Luffman J \& Sussman D (2007) The Aboriginal labour force in Western Canada. Perspectives January 2007 issue. Catalogue no. 75-001-XIE. Ottawa, ON: Statistics Canada; available at http://www.statcan.gc.ca/pub/75-001-x/10107/ 9570-eng.pdf.

30. Martel L, Malenfant EC, Morency JD et al. (2011) Projected trends to 2031 for the Canadian labour force. Canadian Economic Observer August 2011 issue. Ottawa, ON: Statistics Canada; available at http://www.statcan.gc.ca/ pub/11-010-x/2011008/part-partie3-eng.htm

31. Vozoris N \& Tarasuk V (2003) Household food insufficiency is associated with poorer health. J Nutr 133, 120-126.

32. Gucciardi E, Vogt JA, DeMelo M et al. (2009) Exploration of the relationship between household food insecurity and diabetes in Canada. Diabetes Care 32, 2218-2224.

33. Muirhead V, Quiñonez C, Figueiredo R et al. (2009) Oral health disparities and food insecurity in working poor Canadians. Community Dent Oral Epidemiol 37, 294-304.

34. Whitaker RC, Phillips SM \& Orzol SM (2006) Food insecurity and the risks of depression and anxiety in mothers and behavior problems in their preschool-aged children. Pediatrics 118, e859-e868.

35. Currie J \& Madrian BC (1999) Health, health insurance and the labour market. In Handbook of Labour Economics, vol. 3, pp. 3309-3415 [O Ashenfelter and D Card, editors]. Amsterdam: Elsevier.

36. Bound J, Schoenbaum M \& Waidmann T (1995) Race and education differences in disability status and labour force attachment in the health and retirement survey. J Hum Resour 30, Suppl., S227-S267.

37. Wolfe B \& Hill S (1995) The effect of health on the work effort of single mothers. J Hum Resour 30, 42-62.

38. Hamelin AM, Habicht JP \& Beaudry M (1999) Food insecurity: consequences for the household and broader social implications. J Nutr 129, Suppl. 2S, 525S-528S.

39. Knutsson A (2003) Health disorders of shift workers. Осcup Med 53, 103-108.

40. Härmä M, Tenkanen L, Sjöblom T et al. (1998) Combined effects of shift work and lifestyle on the prevalence of insomnia, sleep deprivation and day time sleepiness. Scand J Work Environ Health 24, 300-307.

41. Bøggild H \& Knutsson A (1999) Shift work, risk factors and cardiovascular disease. Scand J Work Environ Health 25, 85-99.

42. Knutsson A, Akerstedt T, Jonsson BG et al. (1986) Increased risk of ischaemic heart disease in shift workers. Lancet 2, 89-92.

43. Morikawa Y, Nakagawa H, Miura K et al. (1999) Relationship between shift work and onset of hypertension in a cohort of manual workers. Scand J Work Environ Health 25, 100-104. 
44. Tüchsen F, Jeppesen HJ \& Bach E (1994) Employment status, non-daytime work and gastric ulcer in men. Int $J$ Epidemiol 23, 365-370.

45. Megdal SP, Kroenke CH, Laden F et al. (2005) Night work and breast cancer risk: a systematic review and metaanalysis. Eur J Cancer 41, 2023-2032.

46. Backé EM, Seidler A, Latza U et al. (2012) The role of psychosocial stress at work for the development of cardiovascular disease: a systematic review. Int Arch Occup Environ Health 85, 7-79.

47. Clark C, Pike C, McManus S et al. (2011) The contribution of work and non-work stressors to common mental disorders in the 2007 Adult Psychiatric Morbidity Survey. Psychol Med 42, 829-842.

48. Shirom A (2003) The effects of work stress on health. In The Handbook of Work and Health Psychology, pp. 63-82 [MJ Schabracq, JAM Winnubst and CJ Cooper, editors]. Chichester: John Wiley \& Sons.

49. Wilkins K \& Beaudet MP (1998) Work stress and health. Health Rep 10, 47-62.

50. Neamtan N (2005) The social economy: finding a way between the market and the state. Policy Options JulyAugust issue, 71-76.
51. Mendell M (2002) The social economy in Québec. Discourse and strategies. In Critical Political Studies: Debates and Dialogues for the Left, pp. 468-502 [E MacDonald and A Bakan editors]. Montreal, QC: McGill-Queen's Press.

52. Health Canada (2007) Canadian Community Health Survey Cycle 2.2, Nutrition (2004): Income-Related Household Food Security in Canada Supplementary Data Tables. Ottawa, ON: Health Canada; available at http://www.hc-sc.gc.ca/fn-an/ surveill/nutrition/commun/supp_table_tableau-eng.php

53. Government of Quebec (2010) Government Action Plan to Combat Poverty and Social Exclusion 2004-2010. Quebec, QC: Government of Quebec, available at http://www. mess.gouv.qc.ca/grands-dossiers/lutte-contre-la-pauvrete/ plan_en.asp

54. Kirkpatrick S \& Tarasuk V (2003) The relationship between low income and household food expenditure patterns in Canada. Public Health Nutr 6, 589-597.

55. Tarasuk V (2001) A critical examination of communitybased responses to household food insecurity in Canada. Health Educ Behav 28, 487-499.

56. Vozoris N, Davis B \& Tarasuk V (2002) The affordability of a nutritious diet for households on welfare in Toronto. Can J Public Health 93, 36-40. 